\title{
THE DEVELOPMENT OF DIGITAL COMPETENCE OF PRIMARY SCHOOL STUDENTS' ACCORDING TO PRINCIPLES OF NUS
}

\section{Iryna Tkachuk ${ }^{1}$}

DOI: https://doi.org/10.30525/978-9934-26-050-6-52

Modern students, the digital generation, don't want any more to wait passively for knowledge that is passed on slowly, logically and successively by the teacher. The new generation of children wants interactivity and multitasking, quick information, they love visual pictures, short videos. Children tend to learn together with each other, share their experience, implement joint projects. They value things that can be immediately tried in practice and are much less receptive to a dry theory detached from modern life. Therefore, the task of a primary school teacher is to organize the educational process in such a way that students should not be afraid, but want to ask questions, develop their creativity and imagination, independence, maintain cognitive activity. We must create conditions for the harmonious entry of a child into the educational environment, maintaining his/her health and emotional well-being.

\footnotetext{
${ }^{1}$ Primary school teachers of Chernivtsi gymnasium № 2, Ukraine
} 
Primary school subjects have a special role, as studying them, the foundations of worldview, the learner's personality, the ability to live in an unstable world are formed, modern forms of communication are learned, the ability to perceive information and to make deliberate decisions is developed.

According to the «New Ukrainian School» Concept and the State Standard of Primary Education, the educational process in the school should be focused on the formation and development of vital competencies. Among 10 key competencies, which «children should acquire while studying various subjects at all stages of education», is the information and digital competence, which includes:

- both confident, and at the same time critical application of information and communication technologies (ICT) for creation, search, processing, exchange of information at work, in public life and private communication;

- information and media literacy, basics of programming, algorithmic thinking, work with databases, Internet security and cybersecurity skills;

- understanding the ethics of work with information (copyright, intellectual property, etc.) [1; 2].

This competence is the most modern and dynamic, it demands, first of all, from the teacher, who works with a child, to improve oneself constantly, to search for innovations that can be later implemented during the interaction with children. The teacher should realize that what, was a novelty yesterday, is relevant today, and it will be long-standing tomorrow.

The use of Computer Technology and the Internet during interaction with primary school learners provides an opportunity to improve the ways of organization of the educational process, make it more innovative, interesting, accessible and stimulate students' interest in learning. Thanks to the use of multimedia teaching aids, lessons become dynamic, bright, diverse in genres, and their effectiveness increases. After all, children's range of interests expands, the material being studied is perceived differently. They learn to think creatively, to express their thoughts more fully and accurately, to show their individual abilities, to overcome certain difficulties in learning, to formulate questions independently, to solve problems and organize a creative process, with a focus on solving of current life problems. And these are the most important steps in the formation of life competencies of the personality.

These tasks can be implemented at primary school lessons when teaching students to analyze, process and effectively use information (including media and digital), as well as to create their own media products (projects, presentations, word clouds, own puzzles and crossword puzzles, QR codes).

That is why my work consists of different methods, types and forms of activities, which are based on the use of various electronic educational resources. 
Online games are not only a good way to relax during your free time. Educational online games provided a unique opportunity, they help a child both to play and learn something new for yourself. Their implemantation helps to find something cognitive in school subjects, interesting and unconventional ways of problems solving. A child will feel more confident in the classroom, be able to read a word, write a letter, count objects, if among many new icons he or she meets familiar ones. This fact partially offsets the influence of such features as his/her temperament on the pace of work and emotional stability. Therefore, during interaction with my students, interesting programs with interactive exercises, fun animated characters, bright plots and background sound, offered by the Ukrainian multimedia publishing house «SmartKids» are used [3] as well as the game platform Kahoot developed by Norwegian scientists.

Kahoot is a relatively new platform for creating online quizzes, tests and surveys that can be used effectively for didactic purposes. Students have the opportunity to do tests created by a teacher in the form of games on their tablets, laptops, smartphones, that is on any device that has access to the Internet. Tasks created in Kahoot allow you to attach photos and videos. The pace of quizzes and tests doing is regulated by a teacher when a time limit for each question is introduced, the individual capabilities of children are taken into account.

Nowadays, to participate in the testing, my students have learned to visit the platform and enter the PIN code, which I provide from my computer. It is convenient for them, using their personal devices, to choose the correct answer, the options of which are represented by geometric shapes. When the game begins, students' work is evaluated by two parameters at once: the choice of the correct answer and the speed of the task doing in comparison with classmates [4].

The requirement of current time is the ability to use a QR-code in everyday life (a square picture in which certain information is encoded). Their special appearance makes it easier to read encoded data with modern mobile phones equipped with cameras. It is enough just to train the smartphone camera on the code and you can get access immediately to its contents.

The ways of using QR-codes are endless: on advertising materials, bookmarks, leaflets, posters. QR-codes can be used on information stands, as a video or multimedia comment (in the form of links), for the announcement of the advertisement or other material, they also can be used for developing of excursion routes, where photos with QR-codes are used to link web pages indicating the location of the objects.

There are some cases when I can use QR-codes:

- If the lesson is accompanied with a presentation, you can provide students with handouts including QR-codes for access to interesting applications (hyperlinks to multimedia sources and resources: video applications, audio applications, sites, animations, e-learning publications, libraries). 
- They can be implemented in diagnostic tests to consolidate the learned material. On each task sheet, you can use a printed QR code with the correct answers or as a prompt with a problem-solving algorithm. Students will try to get their own answer before looking at the correct one.

- A hidden hint. The teacher can encode their own hints and then print out the received QR-code together with the task. Everyone who needs a consultation on the topic will receive it in any convenient place, just by reading the code.

- In an educational game such as a quest with tasks in the form of QRcodes; QR Treasure Hunt Generator automatically creates a QR-quiz out of the proposed questions. Then the printed QR codes can be left in the office or, for example, throughout the school yard. Students, thus, can improve not only knowledge but also their physical training.

- In educational puzzles;

- According to the same principle, you can organize a tour around the school. In the office (corridors, library, other rooms) you need to leave a printed QR-code with a link to video, audio or a whole photo album [5].

Every day I get convinced that digital technologies have great importance in all spheres of life and activity of every person, including the youngest student. Influencing the education of the younger generation, often becoming a leading factor in their socialization, spontaneous social learning, digital technologies are turning into a powerful tool of distant learning and additional source of non-formal education. I understand that in order to become a powerful source of information for my students, I have to work ahead, improving my mastery of various technologies.

\section{References:}

1. Kabinet Ministriv Ukrajiny (2019) Derzhavnyj standart pochatkovoji zaghaljnoji osvity [State Standard of Primary Education]. Retrieved from: https://zakon.rada.gov.ua/laws/show/688-2019-\%D0\%BF\#Text (accessed 18 December 2020).

2. Ministerstvo osvity i nauky Ukrajiny (2016) Koncepcija Novoji ukrajinsjkoji shkoly [The Concept of New Ukrainian School]. Kyiv. Retrieved from: https://mon.gov.ua/storage/app/media/zagalna\%20serednya/nova-ukrainska-shkolacompressed.pdf (accessed 18 December 2020).

3. Pedaghoghichnyj eksperyment «Rozumnyky» [Pedagogical experiment «Smart Kids»]. Retrieved from: https://edugames.rozumniki.ua/ (accessed 05 January 2021).

4. Kahoot - servis dlja stvorennja onlajn viktoryn, testiv i opytuvanj [Kahoot learning platform for online quizzes, tests and surveys]. Retrieved from: https://kahoot.com/schools-u/_(accessed 12 January 2021).

5. Ghenerator QR-kodiv [QR-code generator]. Retrieved from: https://creambee.ru/qr-code-generator/ (accessed 18 February 2021). 